\title{
Comparison of histopathological characteristics and clinical behavior of acquired cholesteatoma
}

\author{
Edinilmiş kolesteatomun semptomlarının ve histopatolojik özelliklerinin karşılaştırılması
}

Mahmood SHISHEGAR, Mohammad Javad ASHRAF

\begin{abstract}
Objective: Acquired cholesteatoma is a severe middle-ear pathology affecting both adults and children. The clinical behavior of cholesteatoma depends on the histopathological characteristics of the disease. The present study aimed to compare the histophathological characteristics of acquired cholesteatoma in patients who had undergone tympanomastoidectomy.
\end{abstract}

Patients and Methods: This retrospective chart analysis was conducted on 370 patients who had undergone tympanomastoidectomy presenting with the pathological indication of cholesteatoma. All cholesteatoma specimens were collected intraoperatively and were preserved for histopathological examination. The patients were divided into two groups according to the histopathological findings: 1- patients with pure cholesteatoma 2- patients with cholesteatoma plus other pathologies. Then, the two groups were compared regarding the clinical variables, including age, gender, duration of disease, occurrence of relapse, and complications.

Results: No significant difference was found between the two groups regarding the clinical variables. Nevertheless, the incidence of pure cholesteatoma was higher among the patients who had experienced the recurrence of the disease and underwent tympanomastoidectomy one more time.

Conclusion: In the present study, no significant difference was observed between the two histopathologically different groups regarding the clinical variables, except for recurrence rate.

Keywords: Acquired cholesteatoma, Clinical and histopathological features, Tympanomastoidectomy

Mahmood Shishegar (凶)

Department of Otolaryngology, Head and Neck Surgery, Shiraz University of Medical Sciences, Shiraz, Iran.

e-mail: med.sums.ac.ir@gmail.com

Mohammad Javad Ashraf,

Department of Pathology, Shiraz University of Medical Sciences, Shiraz, Iran.
ÖZET

Amaç: Edinilmiş kolesteatom hem yetişkinleri, hem de çocukları etkileyen ciddi bir orta kulak patolojisidir. Kolesteatomun klinik özellikleri, hastalığın histopatolojik özelliklerine bağlıdır. Bu çalışmada, timpanomastoidektomi uygulanan hastalarda edinilmiş kolesteatomun histopatolojik özelliklerinin karşılaştırılması amaçlanmıştır.

Hastalar ve Yöntem: $\mathrm{Bu}$ retrospektif çalışma 370 hasta üzerinde gerçekleştirilmiştir. Patolojik olarak kolesteatom tesbit edilen hastalara timpanomastoidektomi uygulanmıştır. Tüm kolesteatom örnekleri intraoperatif toplanmış ve histopatolojik inceleme için muhafaza edilmiştir. Hastalar histopatolojik özelliklerine göre iki gruba ayrılmışlardır: 1. saf kolesteatomlu hastalar, 2. kolesteatom ile birlikte diğer patolojileri olan hastalar. Ardından, iki grup arasında yaş, cinsiyet, hastalık süresi, hastalığın tekrarlaması ve komplikasyonlar da dahil olmak üzere klinik özellikler karşılaştırılmıştır.

Bulgular: Klinik değişkenler açısından iki grup arasında istatistiki olarak bir fark bulunmamıştır. Bununla birlikte, saf kolesteatom insidansı, hastalığ1 tekrarlayan ve bir kez daha timpanomastoidektomi uygulanan hastalarda daha yüksek bulunmuştur.

Sonuç: $\mathrm{Bu}$ çalışmada, hastalığın anlamlı tekrarlama oranı hariç, iki farklı histopatolojik grup arasında klinik değişkenlikler açısından istatistiki olarak bir fark gözlenmemiştir.

Anahtar kelimeler: Edinilmiş kolesteatom, Klinik ve histopatolojik özellikler, Timpanomastoidektomi

\section{Introduction}

Cholesteatoma is a cyst-like lesion of the temporal bone including matrix and perimatrix. It is characterized by the existence of a keratinized stratified squamous epithelium (matrix) which is surrounded by a mesenchymatous granulation tissue (perimatrix) inside any pneumatized portion of the temporal bone [1]. Cholesteatoma most frequently involves the middle ear and mastoid, but it may develop at any place in the air-filled area of the temporal 
bone [2]. The annual incidence of cholesteatoma was about 3 and 9 per 100000 in children and adults, respectively [3]. Cholesteatoma can be either congenital or acquired [4]. The acquired type affects children as well as adults, while the congenital type is specific to childhood. Acquired cholesteatoma is the most common type and is associated with chronic otitis media (COM). Middle ear cholesteatoma is characterized by a severe inflammatory reaction that results in active destruction in tissue and bone [5, 6]. Middle ear cholesteatoma can cause hearing loss and occasionally facial nerve palsy and it can recur after surgical treatment [7]. The only treatment known for cholesteatoma is tympanomastoidectomy which is done using two techniques, namely wall-down and wall-up [8]. Up to now, studies have shown inconsistent findings regarding the difference between cholesteatoma behavior among children and adults [3]. Yet, the histopathological differences in surgical specimens can explain different behaviors of cholesteatoma in the patients [8]. Therefore, the current study aims to compare the histopathological structure of acquired cholesteatoma in the patients undergoing tympanomastoidectomy.

\section{Patients and Methods}

This retrospective chart analysis was conducted on 370 patients who had undergone tympanomastoidectomy for COM, with specimens submitted for pathological review between 2004 and 2009. This study has been approved by our research ethics committee. Among the patients admitted to our otorhinolaryngology referral center, 108 were in the pediatric age group $(<18$ years $)$ and the rest were adults $(>18$ years). Diagnosis of cholesteatomatous COM and presence of matrix and perimatrix in the cholesteatoma were considered as the inclusion criteria in this study. On the other hand, the patients who presented with congenital cholesteatoma were excluded from the study. All the patients signed written informed consents to participate in the study and completed the demographic questionnaires. These patients were evaluated with regard to detailed history, thorough otological examination, and full audiological assessment. Then, the patients underwent tympanomastoidectomy and all cholesteatomas were surgically removed. The collected specimens were immediately fixed in $10 \%$ formaldehyde for histopathological examination. The biopsies were cut into $5 \mathrm{~lm}$ thick sections and stained with $\mathrm{H}$ and $\mathrm{E}$ method for histopathological examination.

According to the histopathological findings, the patients were divided into two groups:

1- Pure cholesteatoma

2- Cholesteatoma plus other pathologies, including chronic inflammation, tympanosclerosis, cholesterol granuloma, glandular metaplasia, giant cell foreign body reaction, granulation tissue, and aural polyp.

These two groups of patients were then compared regarding age, gender, duration of disease, occurrence of relapse, and complications.

\section{Statistical analysis}

The statistical analyses were performed using the SPSS statistical software (version 16.0). Chi-square test was used to determine the correlation between the histopathological findings and the clinical variables. Besides, $\mathrm{P}$ values less than 0.05 were considered as statistically significant.

\section{Results}

All the patients underwent surgery for an acquired middle ear cholesteatoma and the operative specimens were all collected. Among the 262 adults, 141 patients (69.5\%) were male and 121 (72.5\%) were female. Also, among 108 children, 62 patients $(30.5 \%)$ were boys and $46(27.5 \%)$ were girls. The age of the patients ranged from 5 to 67 years old. Moreover, 228 patients $(62 \%)$ had pure cholesteatoma and 142 ones (38\%) were in the second group. Thus, pure cholesteatoma pathology was much more common among the patients compared to cholesteatoma with other pathologies. The frequency of pathologies in cholesteatoma plus other pathologies group has been presented in Table I.

Table I. The frequency of pathologies in cholesteatoma plus other pathologies group

\begin{tabular}{lcc}
\hline & Number & Percent (\%) \\
\hline Chronic inflammation & 54 & 31 \\
Aural polyp & 40 & 23 \\
Tympanosclerosis & 30 & 17 \\
Cholesterol granuloma & 20 & 11.5 \\
Glandular metaplasia & 9 & 5 \\
Giant cell foreign body & 8 & 4.5 \\
reaction & 8 & 4.5 \\
Granulation tissue & 6 & 3.5 \\
Other & 175 & 100 \\
Total & & \\
\hline
\end{tabular}


The study results revealed no significant difference between the two groups in the terms of age $(\mathrm{P}=0.4)$ and gender $(\mathrm{P}=0.19)$ (Table II). In addition, no significant correlation was observed between the histopathological findings and duration of the disease $(\mathrm{P}=0.47)$ (Table II).

The incidence rates of otorrhea and hearing loss among the patients with pure cholesteatoma were $87 \%$ and $68 \%$, respectively. These symptoms were also detected in respectively $85 \%$ and $61 \%$ of the patients who had cholesteatoma plus other pathologies. The total incidence rate of other symptoms, including tinnitus, otalgia, vertigo, headache, nausea, vomiting, and mastoid swelling was $30 \%$ among all patients. The results of the present study indicated that there was no correlation between the symptoms of the patients at presentation time and the histopathological findings $(\mathrm{P}>0.05)$. Among the 370 patients under study, 129 ones (about 35\%) experienced the recurrence of the disease. They showed the recurrence of symptoms and underwent a second tympanomastoidectomy treatment. Additionally, most of the relapse and revision cases had pure cholesteatoma in their pathology reports which was statically significant (Table II). Furthermore, 31 (8.5\%) out of the 370 patients presented, developed complications after tympanomastoidectomy. The reported complications were deafness, facial nerve palsy, wound infection, and bleeding. However, no significant difference was found between the two groups regarding the occurrence of complications (Table II).

\section{Discussion}

Acquired cholesteatoma is characterized by aggressive expansion leading to the destruction of the ossicular chain and other surrounding bony structures. According to the histopathological findings, it is defined as a multilayered squamous epithelium (matrix) surrounded by a mesenchymatous granulation tissue (perimatrix). Up to now, studies have shown inconsistent findings regarding pediatric and adult cholesteatoma. On one hand, some studies have revealed that pediatric cholesteatomas are less extensive, leading to a lower rate of complications [9-11].

Other studies, on the other hand, have indicated that pediatric cholesteatomas are more aggressive and have more extensive growth patterns [12-16].

Numerous studies have compared the histopathological differences between pediatric and adult cholesteatomas. They have investigated the histopathological aspects, such as perimatrix thickness and degree of inflammation, among various age groups $[8,17,18]$. However, paying attention to other dimensions, such as comparing the histopathology of cholesteatomas with different clinical variables, may result in more helpful information. The present study aimed to determine the correlation between the histopathological findings and clinical variables of acquired cholesteatoma, including age, gender, disease duration, relapse, and complications. Quaranta et al. [19] stated that the histopathological characteristics of the perimatrix might explain the clinical differences between pediatric and adult cholesteatomas. Dornelles et al. [8] showed no differences between the adults and children concerning the histopathological characteristics of acquired cholesteatoma, which is consistent with the results of the present study. Similarly, Welkoborsky et al. [17] could not identify any obvious differences between adult and pediatric cholesteatomas in the cellular level. Therefore, the more

Table II. The comparison of clinical variables in the groups according to the histopathological findings

\begin{tabular}{|c|c|c|c|c|c|}
\hline & & $\begin{array}{c}\text { Pure cholesteatoma } \\
\text { N (\%) }\end{array}$ & $\begin{array}{c}\text { Cholesteatoma plus } \\
\text { other pathologies } \\
\text { N (\%) }\end{array}$ & Total N (\%) & $P$ value \\
\hline \multirow{2}{*}{ Age } & $<18$ years & $63(27.6)$ & $45(31.7)$ & $108(29.2)$ & \multirow{2}{*}{0.40} \\
\hline & $>18$ years & $165(72.4)$ & $97(68.3)$ & $262(70.8)$ & \\
\hline \multirow{2}{*}{ Gender } & Male & $119(52)$ & $84(59)$ & $203(54.8)$ & \multirow{2}{*}{0.19} \\
\hline & Female & $109(48)$ & $58(41)$ & $167(45.2)$ & \\
\hline \multirow{2}{*}{$\begin{array}{l}\text { Duration of ear } \\
\text { discharge }\end{array}$} & $<5$ years & $83(36.5)$ & $57(40)$ & $140(37.8)$ & \multirow{2}{*}{0.47} \\
\hline & $>5$ years & $145(63.5)$ & $85(60)$ & $230(62.2)$ & \\
\hline \multirow{2}{*}{ Complication } & Yes & $19(8.3)$ & $12(8.5)$ & $31(8.4)$ & \multirow{2}{*}{0.40} \\
\hline & No & 209 (91.7) & $130(91.5)$ & 339 (91.6) & \\
\hline \multirow{2}{*}{ Revision case } & Yes & $92(40)$ & $37(26)$ & $129(34.8)$ & \multirow{2}{*}{$<0.05$} \\
\hline & No & $136(60)$ & $105(74)$ & $241(65.2)$ & \\
\hline
\end{tabular}


invasive pattern of pediatric cholesteatoma may depend on other parameters, such as severe inflammation, disturbed middle ear ventilation, or decreased calcium salt content of pediatric bone $[2,20]$. On the basis of the recent findings, one may conclude that "in the absence of concern for other pathology, intraoperative findings of cholesteatoma are adequate to confirm diagnosis in patients undergoing tympanomastoidectomy for chronic otitis media without the use of histopathology" [21]. This study also revealed no significant relationship between the patients' gender and the histopathological findings.

In one study, otorrhea, otalgia, and hearing loss were the most prevalent symptoms in both primary (PAC) and secondary (SAC) cholesteatoma patients [22]. In our study, most of the patients also presented with otorrhea and hearing loss. Nonetheless, no significant difference was observed between the two groups regarding the incidence rates of these symptoms.

Early diagnosis and effective treatment of the complications are the bases for a good prognosis [23]. Vikram et al. [22] evaluated the clinicopathologic behavior of complications in PAC and SAC cholesteatoma. They observed that presence of cholesteatoma resulted in a 2.3fold increase in the risk of complications. In another study, 422 (12.54\%) out of the 3,364 patients with suppurative otitis media (acute and chronic) returned with complications [24]. According to the present study findings, $8.4 \%$ of the patients presented with complications after tympanomastoidectomy, but no significant difference was found between the two groups in this regard. In two separate studies, Schraff and Strasnick [25] and De Corso et al. [26] respectively reported the recurrence rate of cholesteatoma to be $16 \%$ and $26.6 \%$ in the children undergoing surgical resection. In this study, nearly $35 \%$ of the patients experienced the recurrence of the disease. Moreover, the patients with pure cholesteatoma pathology had a significantly higher risk of recurrence.

In conclusion, in the present study, no significant differences were observed between the two histopathologically different groups regarding the clinical variables, except the patients with pure cholesteatoma pathology showed higher risk of recurrence.

\section{Conflict of Interest}

The author have no financial or commercial conflicts of interest.

\section{Acknowledgement}

Authors would like to thank Dr. Sajjad Dehghani for improving the English language usage in the manuscript.

\section{References}

1. Ferlito AKO, Devaney A, Rinaldo CM, Milroy BM, Wenig SI, McCabe BF. Clinicopathological consultation: Ear cholesteatoma versus cholesterol granuloma. Ann Otol Rhinol Laryngol 1997; 106:79. doi: 10.1177/000348949710600114

2. Bassiouny M, Badour N, Omran A, Osama H. Histopathological and immunohistochemical characteristics of acquired cholesteatoma in children and adults. Egypt J Ear Nose Throat Allied Sci 2012; 13:7-12. doi:10.1016/j.ejenta.2012.02.007

3. Dornelles C, da Costa SS, Meurer LS, Rosito LCPS, da Silva AR, Alves SL. Comparison of acquired cholesteatoma between pediatric and adult patients. Eur Arch Oto-Rhino-Laryngol 2009; 266: 1553-61. doi:10.1007/s00405-009-0957-0

4. Persaud R, Hajioff D, Trinidade A, et al. Evidence-based review of aetiopathogenic theories of congenital and acquired cholesteatoma. J Laryngol Otol 2007; 121:1013-9. doi: $10.1017 / \mathrm{S} 0022215107000503$

5. Albino AP, Kimmelman CP, Parisier SC. Cholesteatoma: a molecular and cellular puzzle. Otol Neurotol 1998; 19:7-19.

6. Aberg B, Westin T, Tjellstrom A, Edstrom S. Clinical characteristics of cholesteatoma. Am J Otolaryngol 1991; 12:254-8. doi:10.1016/0196-0709(91)90002-W

7. Yamamoto-Fukuda T, Hishikawa Y, Shibata Y, Kobayashi T, Takahashi H, Koji T. Pathogenesis of middle ear cholesteatoma: a new model of experimentally induced cholesteatoma in Mongolian gerbils. Am J Pathol 2010; 176:2602-26. doi:10.2353/ajpath.2010.091182

8. Dornelles C, Costa SSD, Meurer LS, Schweiger C. Correlation of cholesteatomas perimatrix thickness with patient's age. Braz J Otorhinolaryngol 2005; 71:792-7. 10.1590/S003472992005000600017

9. Sheehy JL. Management of cholesteatoma in children. Adv Otorhinolaryngol 1978; 23:58-64.

10. Tos M. Treatment of cholesteatoma in children: A long-term study of results. Otol Neurotol 1983; 4:189-97.

11. Edelstein DR, Parisier SC, Han JC. Acquired cholesteatoma in the pediatric age group. Otolaryngol Clin North Am 1989; 22:955.

12. Glasscock ME, Dickins JR, Wiet R. Cholesteatoma in children. Laryngoscope 1981; 91:1743-53.

13. Ruah CB, Schachern PA, Paparella MM, Zelterman D. Mechanisms of retraction pocket formation in the pediatric tympanic membrane. Arch Otolaryngol Head Neck Surg 1992; 11:1298. doi:10.1001/archotol.1992.01880120024005.

14. Bujia J, Holly A, Antoli-Candela F, Tapia MG, Kastenbauer E. Immunobiological peculiarities of cholesteatoma in children: quantification of epithelial proliferation by MIB 1. Laryngoscope 1996; 106:865-8. doi: 10.1097/00005537199607000-00015

15. Palva A, Karma P, Karja J. Cholesteatoma in children. Arch Otolaryngol Head Neck Surg 1977; 103:74. doi:10.1001/ archotol.1977.00780190054003

16. Sudhoff H, Dazert S, Gonzales AM, et al. Angiogenesis and angiogenic growth factors in middle ear cholesteatoma. Otol Neurotol 2000; 21:793-8.

17. Welkoborsky HJ, Jacob RS, Hinni ML. Comparative analysis 
of the epithelium stroma interaction of acquired middle ear cholesteatoma in children and adults. Europ Arch Oto-RhinoLaryngol 2007; 264:841-8. doi:10.1007/s00405-007-0328-7

18. Dornelles C, Meurer LS, De Costa SS, Schweiger C. Histologic description of acquired cholesteatomas: comparison between children and adults. Braz J Otorhinolaryngol 2006; 72:641-8. doi:10.1590/S0034-72992006000500010

19. Quaranta A, Resta L, Santangelo A. Otomastoid cholesteatoma in children: histopathological findings. Int J Pediatr Otorhinolaryngol 1986; 12:121-6. doi:10.1016/ S0165-5876(86)80069-6

20. Sade J, Fuchs C. A comparison of mastoid pneumatization in adults and children with cholesteatoma. Europ Arch OtoRhino-Laryngol 1994; 251:191-5. doi:10.1007/BF00628421

21. Kircher ML, Thottam PJ, Bojrab DI, Babu SC. Utility and cost analysis of cholesteatoma histopathologic evaluation. The Laryngoscope 2013; 124:538-40. doi: 10.1002/lary.24282

22. Vikram BK, Udayashankar SG, Naseeruddin K, Venkatesha
BK, Manjunath D, Savantrewwa IR. Complications in primary and secondary acquired cholesteatoma: a prospective comparative study of 62 ears. Am J Otolaryngol 2008; 29:1-6. doi:10.1016/j.amjoto.2006.11.014

23. Leskinen K. Complications of acute otitis media in children. Curr Allergy Asthma Rep 2005; 5:308-12. doi:10.1016/j. ijporl.2003.10.018

24. Mostafa BE, El Fiky LM, El Sharnouby MM. Complications of suppurative otitis media: still a problem in the 21 st century. ORL 2009; 71:87-92.

25. Schraff SA, Strasnick B. Pediatric cholesteatoma: a retrospective review. Int J Pediatr Otorhinolaryngol 2006; 70:385-93. doi:10.1016/j.ijporl.2005.10.006

26. De Corso E, Marchese MR, Scarano E, Paludetti G. Aural acquired cholesteatoma in children: surgical findings, recurrence and functional results. Int J Pediatr Otorhinolaryngol 2006; 70:1269-73. doi:10.1016/j.ijporl.2006.01.006 